\title{
The Promise of Decent Care and the Problem of Poor Working Conditions: Double Movements Around Live-In Care in Austria
}

\author{
Brigitte AULENBACHER ${ }^{1}$, Michael LEIBLFINGER ${ }^{2}$, and Veronika PRIELER ${ }^{3}$ \\ Johannes Kepler University Linz
}

\begin{abstract}
Over the last decades, the marketization of live-in care for the elderly in Austria has been accompanied by new forms of regulation and the contestation surrounding this type of care provision. The article analyzes this process as a Polanyian double movement - the movement of a market-driven provision of care and organization of care work, and countermovements seeking protection from its effects - and asks to what extent the provision of decent care and decent work are affected. Drawing on policy and media analyses as well as interviews with representatives of brokering agencies and other stakeholders in the field, we show how live-in care is embedded in the Austrian care regime, how its marketization entails contradictions between decent care and poor working conditions and how care disputes and attempts to regulate the model have emerged.
\end{abstract}

Keywords: Polanyian double movement, Austrian care regime, marketization of livein care, labor disputes, care disputes, regulation of care

\section{Introduction}

Over the last decades, many countries have witnessed an economic shift in the field of caring and care work, including domestic work and care. In particular, new markets for live-in care for the elderly have emerged and are growing. In Austria, care agencies - both in the form of for- as well as non-profit organizations - are booming and have become powerful actors on the care market, increasingly substituting individual commodification of caring and care work by organized or corporated forms. They compete with each other, with comparable care agencies

\footnotetext{
${ }^{1}$ Brigitte Aulenbacher is a professor in social theory and social analysis and head of the Department for the Theory of Society and Social Analyses at the Johannes Kepler University Linz (brigitte.aulenbacher@jku.at).

${ }^{2}$ Michael Leiblfinger is a research assistant at the Johannes Kepler University Linz (michael.leiblfinger@jku.at).

${ }^{3}$ Veronika Prieler is a research assistant at the Johannes Kepler University Linz (veronika.prieler@jku.at).
} 
from other countries, and with transnational companies in the care market among which Austria-based firms are the exception. The Austrian live-in care model is being discussed as a forerunner of care marketization in Europe. However, little attention is given to the contestation surrounding and forms of regulation concerning the quality of caring and care work. The article seeks to shed light on the debate around live-in care in Austria. Regarding the theoretical approach, we refer to Karl Polanyi's work and suggest an understanding of the developments in live-in care in terms of a double movement: the movement of the market-driven provision and organization of caring and care work, accompanied by countermovements seeking protection from the effects of marketization. Therefore, the paper introduces our reference to the Polanyian perspective and illustrates the way in which we use it to investigate caring and care work. Subsequently, we present empirical findings from the Austrian team of the project Decent care work? Transnational home care arrangements. ${ }^{4}$ Drawing on regime, policy, and media analyses as well as expert interviews with representatives of brokering agencies and other stakeholders in the field, we discuss two aspects: The paper examines how live-in care is embedded in the Austrian care regime and marketized in the setting of the home care ideal. Thereafter, we analyze the neoliberal Austrian self-employment model of live-in care as part of the market-driven care provision and show how it has led to countermovements like protests of care workers and attempts of stakeholders to modify the model by implementing a quality seal. In the conclusions, the findings are related to the concept of the Polanyian double movement.

\section{Making Use of the Polanyian Concepts of Fictitious Commodities and Double Movement}

Karl Polanyi's masterpiece, The Great Transformation, first published in 1944, offers a number of concepts to better understand the contemporary marketization of caring and care work, the related contestation in the form of care and labor disputes, and attempts to regulate care provision. With regard to current developments in live-in care, his concept of the double movement around the fictitious commodities land (nature), labor, and money proves to be a fruitful analytical tool. Focusing on labor, we suggest adding care (Aulenbacher/Décieux/Riegraf 2018a; Aulenbacher/Leiblfinger 2019; Lutz 2017) and outline, from a Polanyian perspective, the problems which their marketization entails.

The Great Transformation, Polanyi's (2001) economic, social, and cultural history of the industrial and capitalist epoch, is written as a critique of economic liberalization with its dominant idea of the self-regulating market. From his perspective, its implementation was accompanied by the subordination of society to the market: "[I]t means no less than the running of society as an adjunct to the market. Instead of economy being embedded in social relations, social relations are embedded in the economic system" (Polanyi 2001: 60). This does not mean

\footnotetext{
${ }^{4}$ This research is part of the D-A-CH-project Decent Care Work? Transnational Home Care Arrangements, a cooperation of Aranka Benazha, Amanda Glanert, Helma Lutz, Iga Obrocka, and Ewa Palenga-Möllenbeck from Goethe University Frankfurt/Germany; Brigitte Aulenbacher, Michael Leiblfinger, and Veronika Prieler from Johannes Kepler University Linz/Austria; and Karin Schwiter, Jennifer Steiner, and Anahi Villalba from the University of Zurich/Switzerland. It is funded by the German Research Foundation DFG, project no. LU 630/14-1, by the Austrian Science Fund FWF, project no. I 3145 G-29, and by the Swiss National Science Foundation SNSF, project no. 170353 (http://decentcarework.net).
} 
that markets are independent from society; on the contrary, they are often created and shaped through political intervention. ${ }^{5}$ Scholars reading Polanyi's analyses of the nineteenth and the first half of the twentieth century in order to apply them to today's situation proceed from his critique to discuss the development of the last five decades in terms of a neoliberal era exhibiting new forms of market fundamentalism (Block/Somers 2014; Buğra/Ağartan 2007; Burawoy 2015) which has increasingly extended the "commodity fiction" (Polanyi 2001: 75) to further domains of human life.

Polanyi does not identify market exchange - in terms of one organizational principle of the economy among several - as a problem per se. But if markets - as was the case in the liberal creed of the nineteenth century and, as we may add, continues to be the case in the neoliberal creed of our times - are allowed to follow exclusively or predominantly their own mechanisms of supply and demand and "to regulate themselves according to the signals of prices, costs and profits" (Deutschmann 2019: 22), they become destructive (Polanyi 2001: 75ff.). This is evident when considering land (nature), labor, and money, those elements of the industrial and capitalist economy that cannot be produced and did not come into existence for the purpose of being sold in the first place. Polanyi (2001: 75ff.) therefore refers to them as fictitious commodities, as distinct from genuine commodities. Although the dominant (neo)liberal idea, the commodity fiction, has been extended to them and treats them as commodities like others, there are inherent limitations. In the case of labor this means: "Labor is only another name for a human activity which goes with life itself, which in its turn is not produced for sale but for entirely different reasons, nor can that activity be detached from the rest of life, be stored or mobilized" (Polanyi 2001: 75). Similar considerations apply to the marketization of caring and care work and their commodification we have been witnessing under the auspices of neoliberalism over the last decades (Chorus 2013: 237ff.). Understanding care as a human activity that reacts to the contingency of life, aiming to safeguard and sustain life and livelihood by self-care and care for others (Aulenbacher 2020; Klinger 2013; Tronto 2017), caring - like labor - cannot "be detached from the rest of life, be stored or mobilized" (Polanyi 2001: 75). In a Polanyian reading, the exclusively or predominantly market-driven commodification of labor and care tends to jeopardize their character and meaning for sustaining livelihood and social reproduction, as it subordinates them to market mechanisms and could therefore, in his words, "result in the demolition of society" (Polanyi 2001: 75f.).

Polanyi (2001: 79) regards history as the result of a double movement which consists of different ideas, activities, and measures:

It can be personified as the action of two organizing principles in society, each of them setting itself specific institutional aims, having the support of definite social forces and using its own distinctive methods. The one was the principle of economic liberalism, aiming at the establishment of a self-regulating market, relying on the support of the trading classes, and using largely laissez-faire and free trade as its methods; the other

\footnotetext{
${ }^{5}$ Following Margaret R. Somers (2018: 92, emphasis in original), the strength of Polanyi's perspective consists of "recognizing the co-existence of disembeddedness and embeddedness" of the market. This co-existence is empirically not independent from the societal organization and therefore from the relations of power. Nevertheless, market exchange can become the dominant organizational principle subordinating economy and society to its laws through a certain universality of its mechanisms (Deutschmann 2019: 34ff.) and/or through social or political intervention (Polanyi 2001: 141ff.).
} 
was the principle of social protection aiming at the conservation of man and nature as well as productive organization, relying on the varying support of those most immediately affected by the deleterious action of the market - primarily, but not exclusively, the working and the landed classes - and using protective legislation, restrictive associations, and other instruments of intervention as its methods. (Polanyi 2001: 138f.)

Countermovements seeking protection from the movement towards a market-driven economy and society in a Polanyian sense, as Michael Burawoy (2015: 15ff.) systematically summarizes, have in common that they are motivated by the experience of marketization and its effects. They potentially include a wide range of actors (e.g., labor movements, social movements, cooperatives and communities) and measures (state intervention, laws, etc.). This also means that countermovements may be progressive or regressive, emancipatory or anti-emancipatory, democratic or anti-democratic, etc. (Abraham/Aulenbacher 2019). Their results can be paradox, in our case leading to the ex-, de-, or recommodification of labor and care, possibly consolidating or pushing markets towards the next stage of development (Aulenbacher/Décieux/Riegraf 2018a; Burawoy 2015).

Investigating the disputes surrounding caring and care work and attempts to regulate this field of work through the lens of Polanyi's conception does not mean to deny or neglect that there are more and other causes of labor and care disputes (Artus et al. 2017; Dörre/Ehrlich/Haubner 2014; Rudolph/Schmidt 2019; Völker/Amacker 2015; Winker 2015). The experience of marketization and the search for protection from market-driven dynamics and their destructive effects is one of them. This motive can be articulated independently from or related to other motives like the struggle for equal rights, the struggle against exploitation, the longing for nostalgically idealized care relations, and so forth (Abraham/Aulenbacher 2019; Fraser 2012; Karner/Weicht 2016).

However, research on professional care shows that the core issues being contested in this context include the contradictions between demands and claims concerning decent care and economic requirements which emerge from the market-driven organization of labor and care (Aulenbacher/Décieux/Riegraf 2018a, 2018b; Dammayr 2019; Décieux/Becker/Kutlu 2020; Klinger 2013, 2014; Tronto 2017). To emphasize one central aspect, Maria Dammayr (2019: 32$39,272,316-330)$ discusses emphatic concepts of care and the underlying holistic account as inspiration for comprehensive care and yardsticks to judge the quality of caring. Comprehensive care - professional as well as lay care work - includes elements like interaction and interpersonal relations, communicative and emotional work, the consideration of the needs associated with everyday life, and taking into account the specific biographical circumstances of care givers and care receivers. Notwithstanding that further elements may be significant, comprehensive care attending to the needs of human beings - in terms of self-care and care for others - can be defined as the foundation of decent care and is accompanied by the careful organization of the inevitably difficult asymmetric relationships associated with care. The purpose of comprehensive care is to serve and sustain life and livelihood as an end in itself rather than to subordinate care work to other, not least economic, purposes and thereby to embed it into an instrumental approach that entails care efficiency measures, rationalization, etc., which are part of the market-driven organization of care. The economic shift in the field of care threatens 
working conditions and therefore can put comprehensive care in everyday practice at risk, preventing care workers from performing their work in an adequate manner (Aulenbacher/Dammayr 2014; Aulenbacher/Leiblfinger 2019; Dammayr 2019; Décieux/Becker/Kutlu 2020; Klinger 2013). This contradiction between decent care - guided by ethical and professional standards, by demands and claims of care givers and care receivers to care for themselves and others, etc. - and poor instead of decent working conditions in the increasingly marketized care sector constitutes the experiences that cause care and labor disputes and underscores the need for regulation in many fields of care work (Artus et al. 2017; Amacker/Völker 2015; Winker 2015).

In domestic work and care, labor disputes have a long tradition. They are rooted in the experience of exploitation and oppression associated with the commodification of labor in the private household and female migrant workers' precarious position concerning citizenship and other rights (Anderson/Shutes 2014; Haubner 2017; Lutz 2017). In particular in the Global South, such disputes have become more visible over the last decades, reached the International Labour Organization in 2010 and, in 2011, succeeded in achieving the adoption of the Domestic Workers Convention. This Convention 189 includes equal rights, regulation of employers' responsibilities, limitation of working hours, regulation of working conditions, and the right to form trade unions (Blofield/Jokela 2018). It defines minimum standards of decent work but, as of June 2019, has been ratified by only 29 countries, ${ }^{6}$ Austria not being one of them. In domestic care and work in general and in live-in care in particular, the demands and claims of care receivers or their relatives concerning decent care affect the working conditions of care givers. In many parts of the global care economy the working conditions fail to meet the standards of decent work (Anderson/Shutes 2014). In this situation, the intensified marketization of live-in care and the experience of its negative effects matter, and care and labor disputes have both newly emerged and increased, also in a wealthy European country like Switzerland (Chau/Pelzelmayer/Schwiter 2018; Schilliger 2014; Schilliger/Schilling 2017; Steiner 2020). In Austria, with regards to a Polanyian countermovement, we are witnessing, on the one hand, care disputes and attempts to regulate market-driven live-in care involving many different stakeholders. On the other hand, there are labor disputes of care givers seeking to improve their working conditions which partially overlap with or contradict these care disputes.

\section{Market Creation and the Regulation of Live-In Care in the Austrian Care Regime}

In order to reconstruct the development of live-in care and the related contestation within the context of the Austrian elderly care regime and to analyze the underlying movement of a market-driven commodification of care and countermovements seeking protection, the article draws on various data sources. It refers to regime, policy, and media analyses of Austrian livein care, in-depth analyses of brokering agencies' websites, and expert interviews with agencies' representatives and other stakeholders in the field. Care regimes describe how care work is symbolically, legally, and materially organized and brought to life by everyday conceptions and practices regarding the distribution of care work and services (Bachinger 2014: 129). Providing

\footnotetext{
${ }^{6}$ https://www.ilo.org/dyn/normlex/en/f?p=1000:11300:0::NO:11300:P11300 INSTRUMENT ID:2551460
} 
the context in which live-in care is embedded, the Austrian elderly care regime shapes both its marketization as well as the contestation surrounding this form of care provision. The notion of regime as an interplay of norms, institutions, and policies with social practices highlights the importance of individual and collective actors like agencies or other stakeholders. Based on a comprehensive survey of all Viennese agencies' websites, we analyzed 20 of them in detail and conducted 11 expert interviews with agency representatives, mirroring the live-in care market's organizational diversity. We supplemented this database with 11 expert interviews with relevant stakeholders in the field like, for example, representatives of interest groups as well as institutions and organizations with special responsibilities. We analyzed all interviews in a detailed qualitative content analysis. Finally, we gathered information about an individual case of a widely publicized care dispute from the media ${ }^{7}$.

Austria is an interesting case with regard to questions of decent care and decent work as it has not only become a forerunner of marketization (Shire 2015) but also because the economic shift is linked to the legalization and formalization of live-in care. Furthermore, it is combined with attempts to professionalize live-in care. For all these reasons, we shall reconstruct the history of this marketization process in the following.

Beginning in the early 1990s, an irregular market of live-in care for the elderly developed. Mainly organized through informal networks and a few small brokering agencies, predominately women from neighboring Central and Eastern European countries like the Czech Republic or Slovakia began to work in Austrian households, providing company, cooking and cleaning, assistance in everyday life, and nursing care. Apart from the economic situation in the sending countries, Austria's care regime was a driving force for the establishment of this transnational live-in care market (Österle 2016). Besides the slow expansion of public long-term care facilities and services, care for the elderly was and still is regarded primarily a family matter performed predominately by women (Appelt/Fleischer 2014). This idealized notion of familial and domestic care is further reinforced by the Austrian cash-for-care system, which was introduced as a universal, federal benefit in 1993. The long-term care allowance (Pflegegeld) is not tied to any specific predefined use. It emphasizes recipients' autonomy and choice and strengthens their role as consumers on care markets: "[T]he scheme aims at user-driven developments in the social service sector [...] not by requiring users to buy specific services, but through increased purchasing power in the hands of users" (Österle/Bauer 2012: 269). Combined with high unemployment rates and low pensions in many post-communist countries, resulting in the availability of relatively cheap transnational labor, the cash-for-care scheme, together with the ideal of the home care society, therefore contributes to and stimulates the marketization of live-in care for the elderly.

In 2007, the prevailing irregular practices were legalized and the new profession of personal care (Personenbetreuung) was introduced. Although an employer-employee relationship was made possible by the Home Care Act (Hausbetreuungsgesetz), the neoliberal self-employment model predominated from the outset. It integrates self-employed personal carers into the

\footnotetext{
${ }^{7}$ In addition to these parts we refer to, three in-depth case studies with episodic interviews with care agencies, managers, recruiters, care workers, care receivers, relatives, and two focus groups with care workers and relatives as well as a media analysis of the changes around the COVID-19 pandemic are part of the authors' investigation running from 2016-2021.
} 
general social security system ${ }^{8}$ and has led to a formalization of the care arrangements (e.g., specified tasks, mandatory contracts) (Österle/Bauer 2016).

At the same time, the self-employment model undermines standard social protection and workers' rights that are common in regular employment. Like all self-employed, personal carers are neither eligible for minimum wage and paid vacation nor do working time regulations apply, making live-in care a flexible and relatively cheap option for Austrian middle- and upperclass households. ${ }^{9}$ The market for transnational live-in care has rapidly increased from roughly 9,000 care workers registered with the Austrian Chamber of Commerce in July 2008 (Bachinger 2009: 147) to nearly 62,000 at the end of 2019 (WKO 2020: 11). The majority of care workers come from Romania or Slovakia, 95 percent are female, and most are between 41 and 60 years old; often they are pushed to migrate because of unemployment, low wages, or insufficient pensions in their home countries. In a typical Austrian live-in care arrangement, two carers alternate in two- to three-week shifts as live-ins (Leiblfinger/Prieler 2018). Although the usual remuneration of 60 to 70 Euros per 24 hours of work in Austria does not allow care workers to live outside of the live-in arrangement that includes board and lodging, it does contribute to their own and their families' subsistence in their home countries.

Brokering agencies play a crucial role in this care market. They do not only recruit and place care workers but offer a variety of services to households and - usually to a lesser extent - to care workers. By doing so, they shape many conditions of the care arrangement (e.g., remuneration, duration of shifts) (Österle/Hasl/Bauer 2013). Despite their influence, they assume no liability for the carer's work as care workers bear sole responsibility for the working conditions and the results of their care work (Aulenbacher/Leiblfinger/Prieler 2020). The number of these agencies has risen from around 20 in 2005 (Bachinger 2009: 152) to over 800 at the end of 2019 (WKO 2020: 11), comprising largely sole proprietors and limited liability companies as well as a few non-profit organizations and transnational companies.

To sum up from a Polanyian perspective: the legalization, formalization, and professionalization of live-in care can be understood as part of market creation. On the one hand, the Austrian care market is politically shaped by the embeddedness of live-in care in the welfare and care regime. This is evident in the described public funding, which allows members of the middle and upper classes to maintain their ideal of home care and to purchase the necessary care services. And it corresponds to EU-migration policies, guaranteeing the availability of migrant workers by free movement. On the other hand, considering both the increasing number of agencies based in Austria and an undocumented number of brokers in sending countries, it is a highly competitive market where the mechanisms of supply and demand are effective for two reasons: first, the less protected self-employed status of the care workers compared to regular employment; second, the limited quality control of care services in the cash-for-care scheme compared to other forms of public care provision. The investigated Viennese agencies offer their services in this simultaneously embedded and disembedded market.

\footnotetext{
${ }^{8}$ Coverage is comprehensive, but slightly less extensive compared to employees.

${ }^{9}$ To guarantee the affordability of the legalized model compared to the previous irregular arrangement, a means-tested monthly allowance of up to 550 Euros for care receivers was introduced to cover the social insurance costs that arise for care workers since the legalization.
} 
Live-in care is promoted as a perfect solution for rising care demands, promising relatives relief from demanding care responsibilities and autonomy and individualized care at home to care receivers. Agencies' advertisements present live-in care as a quasi-family arrangement by romanticizing familial care as well as the relations between care receiver and care giver. Pictures show happy elderly people and care workers touching each other like (grand)mother/(grand)father and (grand)daughter. They also show wealthy and well-educated members of middle- and upper-class households well-prepared to host the care workers - who are in turn presented as members of the same class and culture. Carers are portrayed as working under comfortable working conditions for best agers, whom they have to entertain or assist. Multimorbid care receivers and hard work for care givers do not seem to feature in the reality of live-in care.

In their advertising, agencies address people in need of care and their relatives as clients, consumers, or customers who buy a specific product (Prieler 2020). Correspondingly, many agencies offer different care packages, combining language skills, qualification, or work experience of the carer and tasks like housework, company, assistance, medical care, etc., with graduated prices. They couple the promise of decent care with quality control in the households. In case that care workers do not meet the household's expectations or do not get along well with household members - "if the chemistry is not right" 10 (Interview 86: 375-376) - agencies promise, contrary to the notion of quasi-familial care, to exchange care workers free of charge or for additional fees (Aulenbacher/Leiblfinger/Prieler 2020). This highlights the commodification of care work and the character of live-in care, in terms of work and care, as a (fictitious) commodity (Aulenbacher/Leiblfinger 2019; Rossow/Leiber 2017). Furthermore, it shows that the promised quality of services is important to the business model of many agencies because it allows to appeal to clients not only through prices. Even though care workers are also clients of agencies and often pay fees, they are typically not the addressees of their advertisements. This takes into account that, formally, agencies act as intermediaries and not as employers. They are only responsible for brokering self-employed care workers, but not for their living or working conditions. Carers are expected to negotiate these conditions with care receivers or their relatives directly. In other words, the promise of decent care as a strategy to marketize care services while neglecting the problem of poor working conditions is inherent to the Austrian form of organizing live-in care.

Although the brokering of care workers is influenced by its embeddedness in the care market through public funding along the logic of cash-for-care policies, by the ideal of home care, etc., it is nonetheless regarded to be a "free market" (Interview 87: 697) with regard to the competition between agencies and among care workers. In a Polanyian sense, this emphasizes its self-regulation: competition and competitiveness seem to be the essential underlying factors responsible for the status quo of live-in care in terms of care provision as well as the working conditions concerning prices and remuneration, quality of care, working hours, etc. The notion of the free market functions as an ambivalent argument: in favor of the entrepreneurial mode of self-employment and brokering combined with the argument that - given the ability and capacity of care workers as well as agencies to compete - care provision and working conditions are more or less well regulated by the market; and as a counterargument with regard to the

\footnotetext{
${ }^{10}$ Here and throughout, German texts were translated into English by the authors.
} 
undermining of formally or informally accepted minimum standards of decent care and decent work by unfair competition on the market. In this scenario, we can identify efforts to challenge working conditions that are seen as the result of competition on unregulated markets and attempts at market regulation in order to channel the competition towards the provision of highquality care.

This is the scenario we analyze as a Polanyian double movement concerning the contestation surrounding the marketization of live-in care, respectively countermovements concerning the labor and care disputes seeking protection from and the attempts to regulate and tame the market dynamics by different actors, activities, and measures. Agencies in the role not only of brokering live-in care workers but also in that of stakeholders try to influence the market and its regulation according to their own interests, which differ significantly in accordance with their respective organizational characteristics and self-positioning in the field. Some representatives, mostly of bigger agencies, are strongly intertwined with economic or political stakeholders or those rooted in civil society, be it on an informal basis or formally as, e.g., an official in the Chamber of Commerce. Besides the chamber as the institutional representative of all entrepreneurs - which includes both agencies and self-employed carers -, care workers' and care receivers' NGOs, relevant ministries, and trade unions are important stakeholders in the field. Their activities are of interest as they push to further regulate live-in care and the care market.

\section{Double Movements Around Care and Work}

As a result of its legalization, formalization, and professionalization, personal care has become an established part of the Austrian elderly care regime. Nonetheless, there has been critical media reporting ${ }^{11}$ on (new) controversies over the acceptance and future of the practiced self-employment model as well as some initial attempts to improve the situation of care receiver and care workers. The ongoing and increasing marketization and the growing influence of agencies have made live-in care a three-fold issue concerning protection, with the contradiction of decent care without decent work at the core: care receivers and their relatives addressed as consumers should be protected from irregular or non-transparent market-based brokering; live-in care givers should be protected from demands of care receivers and their relatives concerning times of availability and tasks that are not in line with their contracts, from exploitative working conditions, and from agencies making additional, undue profits by administrating payments and participating in the remuneration; care receivers in private households should be protected from improper or inadequate treatment and abuse of trust by care givers in the delicate relationship of caring with all its inherent interdependencies. Notwithstanding the widely shared perspective of a necessary search for protection, the diagnoses of the problems' causes vary just as much as the suggested solutions. In the following, some movements and countermovements around live-in care are detailed, starting with a closer look at the working conditions.

\footnotetext{
${ }^{11}$ E.g., Kurier (2017a, 2018); Falter (2017); Der Standard (2018).
} 


\section{The neoliberal self-employment model as an obstacle to decent working conditions?}

Austria's regulation of live-in care in 2007 aimed to "legalize the use" (Kretschmann 2010: 208) but not to change "the actual working and living conditions" (Kretschmann 2010: 210) of carers. It introduced a neoliberal self-employment model depicting and registering care workers as entrepreneurs and market participants comparable with agencies. Opponents criticize and scandalize this as modern slavery and call for the direct employment of live-in care workers in order to protect them from the negative effects of market dynamics. In addition, they have introduced ideas of decentralized, local flat-sharing, community nurses (e.g., Interview 13), or a substantial expansion of mobile home care services (e.g., Interview 18) into the discussion about alternatives to the dominant home care ideal. These perspectives nevertheless remain a minority position. Many of our interviewees are (mostly) in favor of the dominant self-employment model - some because they do not think there is an affordable alternative for the welfare state and private households, others who hope for improvement as well, and again others who are convinced of the entrepreneurial approach.

Viewing personal carers as market participants puts them in charge of negotiating and establishing their working conditions, their remuneration, and their own self-care needs. At the same time, many agencies are aware of the underlying imbalances between members of households and care workers in any live-in arrangement. They know about the difficulties of direct negotiation and provide carers with support when needed, for example with regard to the (re)negotiation of remuneration and/or free time. By doing so, agencies - in this case as advocates of carers' wants and needs - further shape the conditions live-ins have to work under. Critics of the self-employment model see this as evidence that agencies regulate live-in carers to the extent that they can only formally act as autonomously self-employed while having to accept exploitative and/or disadvantageous contracts. The actual opportunity for direct negotiation and the associated entrepreneurial freedom is taken away from personal carers as they are modulated into a status resembling that of employees without being given any of the rights or benefits regular employment would entail, such as paid vacation or sick leave (Interview 13: 808-863, 1807-1837). In practice, the self-employment of care workers oscillates between formal entrepreneurship and quasi-employment in terms of being restricted by their contracts with agencies and/or households. This is a result of care workers' vulnerable position in the transnational care market and precarious position in Austria.

The self-employment model per se - and not only in its practiced form of precarious and restrictive quasi-employment - further undermines the protective measures stipulated by existing standards, a situation that no Austrian would deem acceptable for themselves, as several our interviewees pointed out (e.g., Interview 10): instead of adhering to normal working hours in line with the regulated exceptions under the Working Time Act (Arbeitszeitgesetz), personal carers may work at any hour or weekday without the benefit of paid overtime or surcharges for working at night or on public holidays. As carers are self-employed - as well as workers in private households who are exempt altogether -, neither families nor agencies have to provide them with occupational safety protection under the Worker Protection Act (ArbeitnehmerInnenschutzgesetz) that would assure, for example, a healthy workplace. The self-employment model therefore is crucial to the radical marketization and commodification of care with its inherent subordination of decent work and decent care, not least with regard to the care 
workers' self-care, care for their own relatives, and further social life. Self-employment in accordance with the neoliberal entrepreneurship has made the Austrian form of live-in care a forerunner of marketization, as it weakens the position of the care workers in terms of protection from poor working conditions.

\section{Decent care provision and poor working conditions?}

To further investigate the contradiction between the promise of decent care for care receivers and the lacking conditions for decent work and (self-)care for care givers, this section takes a closer look at the services offered by agencies and the competition on the care market by emphasizing four significant aspects. The first one is the price- or quality-related competition on the (dis)embedded market and the promise of cheap versus decent care associated with different concepts to marketize caring and care work. Given the high and still rising number of agencies, it comes as no surprise that many interviewees see the fierce competition on the increasingly crowded care market as a problem. From a Polanyian perspective, despite the embeddedness of the care market, growing trans- and international competition between brokering agencies stimulates the market's self-regulation along supply and demand. In order to distinguish themselves from others, agencies offer additional services like hourly, nightly, or short-term home care and some even specialize in dementia or hospice care (Aulenbacher/Leiblfinger 2019). While trying to find their own niche and appealing to customers through their professionalism, they complain about bad apples who ruin the market with price dumping and poor service quality (Steiner et al. 2019) - a perspective that many stakeholders share. "[We] have a polarized market between the large organizations and those that work quality-oriented and agencies that work heavily with dumping prices, where the carers get 30 Euros [a day]" (Interview 89: 378382). Many interviewees see the responsibility for this not only with agencies, but also with households expecting decent care but are unable or unwilling to pay more and thereby facilitate price dumping strategies.

Secondly, besides price dumping, many interviewees criticize the insufficient regulation of the market and personal care as a profession as well as, in particular, the fact that no qualifications are required to register an agency. In terms of a Polanyian countermovement, these criticisms and complaints address institutions which are potentially able to tame the market-driven dynamics by law, obligatory standards, etc. In the eyes of these actors, this lack of regulation has resulted in the rapid increase in the number of agencies. "[T]he high number [of agencies], it simply got confusing, yes. So prices and the market [are] flooded nowadays" (Interview 82: 868873). At the same time, in the public and media discourses, some agencies' lacking nursing or medical qualification is being criticized with claims like "any lorry driver today can broker care workers on the side" (Kurier 2017a). Because of the lack of skills in some agencies, and because some agencies carry out the needs assessment by telephone or (e)mail and not directly at the care receiver's home as they are legally required to, the matching process often entails problems of qualification and concerning the guarantee and quality of the promised service: agencies broker care workers who do not meet the requirements or who are overstrained and may quit the arrangement after a short time because the care receiver's health status or the household situation differs from the information they received from the agency (Interview 82: 371-374; 
Interview 84: 750-765; Interview 20: 387-399). In this sense, seeking protection from the market-driven dynamics requires further professionalization of live-in care.

Third, the matching of the demands of households - the care receivers and their relatives and the recruited care givers is not always adequate, which is why we repeatedly find the question of qualification raised in our interviews: the discrepancy between the often high nursing care needs of care receivers ${ }^{12}$ and the insufficient qualifications of care workers. "Personal care givers are brokered, who often have no training [...]. But then there are often [...] very dependent care receivers where care givers end up. They are not allowed to nurse them, they only care for them, but in practice they do everything" (Interview 11: 53-58). This reflects the Austrian regulation which does not require formal training in caring or nursing from personal carers ${ }^{13}$ but nonetheless allows them to perform nursing and (simple) medical tasks via delegation from a nursing or medical professional (Leiblfinger 2020; Leiblfinger/Prieler 2018; Schaup 2020). The lack of formal training or awareness regarding rights and duties, sometimes in combination with low language skills, can lead to problems with, e.g., medication. Since the whole model is based on circular migration with underlying economic and welfare gaps, carers are frequently selected not for their skills and qualifications but rather for economic reasons (e.g., Interview 86: 375-377; see Bahna/Sekulová 2019). If the promise of decent care - and we did not interview a single agency that did not promise as much - is based on poor labor conditions, the consequences pertain to both the quality of care and the quality of work: namely if the care workers are not prepared to do the job and face excessive demands, while the health of the care receivers is put at risk. The existing organization of live-in care tends to jeopardize the fictitious commodities labor and care.

Fourth, and by contrast, increasingly there are complaints about difficulties in the recruitment of qualified workers because of rising local wages and improvements in the economic situation in some sending countries, making the Austrian live-in model and circular migration less attractive for many carers (Interview 80: 1235-1245; Interview 81: 1308-1320; Interview 84: 1442-1469). As a solution, some agencies go further east for labor force recruitment. Several interviewees criticize this international competitive strategy on the market as adding to the history of exploitation of migration. While Slovaks were among the first generation of care workers, in the face of recruiting problems in Slovakia, Romania became interesting for agencies as a sending country. This opened up opportunities for exploitation based on information deficits: "Slovaks are already sophisticated, because they already do it for a long time, but the Romanians [...] make rookie mistakes [...]. And agencies [...] use [information gaps] shamelessly, because they get [carers] from far away, who know nothing at all, and then exploit them financially" (Interview 11: 418-425).

These four aspects illustrate how supply and demand are organized around the contradictory relation between the prices for care services, based on cheap labor and poor working conditions, and the promise of high-quality care. Fierce competition and unhindered marketization

\footnotetext{
${ }^{12}$ Almost half of the recipients of the federal allowance for 24-h care have a decreed care level between 5 and the Austrian maximum level of 7 and therefore nursing care needs of at least 180 hours per month, with the other half either at least 120 (level 3) or 160 hours (level 4) (Leiblfinger/Prieler 2018).

${ }^{13}$ If the care receiver claims the federal allowance for 24-h care, personal carers have to meet (low) qualification standards, although these can be waived if as little as six months practical experience are demonstrated.
} 
are seen as problematic, and the associated contestation can be viewed as countermovements against the forces of the free market. Further countermovements - like protests against poor working conditions or attempts to strengthen the regulation of the market - also pertain to these four aspects and, in a Polanyian sense, comprise different actors and activities.

\section{Challenged organizing of care workers in market-driven live-in care}

Against the backdrop of the public debate and critical media coverage of Austria's live-in care and related problems, care workers have started to organize, both of their own accord and by others, such as church-associated or trade union initiatives. Apart from using online networks like Facebook to stay connected, consumer advocates, unions, and the Chamber of Labour criticize "dubious agencies" and advocate for "more fairness, transparency, and quality", a direction which self-organized carer initiatives support (Kurier 2018). For the time being, it remains difficult to judge whether these new forms of organizing have a more "liquid character" (Burawoy 2015: 16) reacting to everyday life experiences of an exhausting commodification of labor putting self-care and care for others in the hands of carers at risk, or whether they represent the beginning of new forms of individual and collective resistance which may form independent initiatives outside of the traditional labor movement.

One example for a countermovement against the radical marketization of live-in care and the related exploitation is the widely publicized case of Elena Popa ${ }^{14}$ : the Romanian personal carer from a village in Banat went public in 2017, reporting what she called "mafia-like structures" (Kurier 2017b) of local agencies in Romania which frequently act as partners for agencies in Austria. Popa accused those agencies not only of siphoning off money from care workers by collecting dubious fees, but also of forging documents. She made her experiences public on Facebook where she shared documents, warnings, and recommendations in a group with over 30,000 care workers. Popa was subsequently sued, she and her husband repeatedly received (sometimes life-)threatening phone calls, and Facebook shut down her group in 2018 after anonymous complaints. Meanwhile, the Austrian partner of the Romanian plaintiff considered her to be a troublemaker and rejected her accusations. Although Popa herself had ultimately become tired of her role as the carers' public figurehead, she still received a lot of support from other personal carers. Until at least 2019, Popa continued to work as a personal carer (Der Standard 2019). Her case became even more complicated when she was sued by a staff member of an Austrian trade union for postings urging care workers to stay away from and not trust that union member. While Popa was acquitted in Austria, the court in Timișoara sentenced her to a fine of 2,000 Euros. In another lawsuit against an agency operator Popa won, yet she lost one against an agency driver, a ruling she appealed. As of 2020, the two-year-old first case is still pending at the European Court of Human Rights (Der Standard 2020).

The developments in Austria are similar to a pattern that is known from other countries in the field of caring and care work as well as in other fields where social protest is motivated by "shared repertoires" in the face of "market-fundamentalism" (Burawoy 2015: 15): an individual protagonist initiates debates, disputes, and protests, and social movements emerge in the respective field. In some countries, including Austria, this led stakeholders in the field of caring,

\footnotetext{
${ }^{14}$ E.g., Der Standard 2019 \& 2020; Falter 2018; Kurier 2017b \& 2018.
} 
like trade unions, to actually recognize the problems (Blofield/Jokela 2018; Schilliger 2014; Schwenken 2006).

For years, personal carers had no lobby in Austria. Since most care workers are self-employed, unions and the Chamber of Labour have no (formal) power of representation as all selfemployed have compulsory membership in the Chamber of Commerce, as do all entrepreneurs. During the public law review process of the Home Care Act in 2007, both the Austrian Trade Union Federation as well as the Federal Chamber of Labour raised several concerns ${ }^{15}$; however, once the law passed, they took little initiative to bring about change. One reason might be that even experts considered the Home Care Act a transitional model within a longer regulatory process (Bachinger 2010: 409). Now, 13 years after the law was enacted, trade unions and many other stakeholders are becoming increasingly involved in live-in care and its future. The current media coverage generally mirrors the situation some interviewees describe when reflecting on the role of the distinct actors in the field (e.g., Interviews 10; 18; 80).

In the Austrian case, alongside many other motives, the new contestation surrounding livein care can be viewed as an unintended consequence of its radical marketization through selfemployment that challenges stakeholders and agencies in their roles. The Chamber of Labour, with mandatory membership of most employees (but not the self-employed), is currently more involved in consumer protection and less influential concerning the working conditions in livein care, and trade unions typically organize those workers in regular employment. Brokering agencies are currently not allowed to employ care workers directly, and forms of quasi-employment through contracts - both those which are intended to protect carers and those which are exploitative - are not covered by the existing structures of collective bargaining and other regulatory mechanisms pertaining to employment conditions. While the ILO's Convention 189 and collective bargaining address the legal regulation of employment and employment conditions, the market-fundamentalist Austrian model of self-employment is essentially detached from many forms of collective engagement and responsibility.

The challenges for trade union organizing under these conditions include the fact that selfemployed carers can hardly be reached at the workplace, that they are abroad during the periods they are not on duty in Austria, and that their working conditions often depend on individual and informal negotiations in the private households (Haidinger 2016). One new stakeholder is the trade union initiative vidaflex, ${ }^{16}$ which has launched efforts to organize care workers alongside other self-employed and small enterprises. This union initiative tries to deal with the circular migration of carers by reaching out to them directly in Romania and offering information on and support in claiming their rights and obligations as self-employed care workers in an attempt to raise awareness about shady agencies (Die Presse 2018). Support, empowerment of personal carers, and representation of their interests is also the aim of the live-in carers' organization Institute for Personal Care (Der Standard 2018; Kurier 2018), founded in 2015. Furthermore, the role of the Chamber of Commerce is contested: while some actors criticize the chamber for representing mainly the interests of agencies but not care workers' issues even though they are dues-paying members, others emphasize that the joint organization of agencies and

${ }^{15}$ 19/SN-40/ME and 34/SN-40/ME

${ }^{16} \mathrm{https}$ //www.ots.at/presseaussendung/OTS 20190328 OTS0197 
personal carers brings the two groups together and thus enables a better balance of interests (Konsument 2018).

Our analysis shows that self-employment is not only an obstacle for the regulation of working conditions but also makes the organizing of care workers difficult. Their everyday practice between entrepreneurship and quasi-employment and the given roles and responsibilities of some collective and corporate actors come into conflict with one another. From a Polanyian perspective, self-employed care workers are a group of workers seeking protection from the market-driven dynamics like others, by building their own countermovements, collaborating with existing ones, and creating new forms of representation of their interests.

\section{Quality seal and market regulation: protection and/or competition?}

Another answer and countermovement to the problematic outcomes of the increased marketization of care is the proposition of the implementation of a quality seal put forward by various actors. This can be understood as an attempt to tame the "wild market" (Interview 86: 1106) in order to reach a higher quality of care services and working conditions. And, at the same time, this countermovement - seeking protection from the impact of market dynamics on care provision and care work - is an intervention of powerful agencies and an example of the attempt to consolidate the market: in the sense of a free, but fair market instead of a Polanyian selfregulating market exclusively or predominantly ruled by supply and demand. These efforts are aimed at influencing the competition in favor of those agencies fulfilling certain conventions by professional self-control or control of relevant stakeholders in the field, like the Federal Ministry of Social Affairs, the Chamber of Commerce, etc. Therefore, in terms of a movement, the seal functions as a justification of the existing live-in care market and has to be considered a concept for better marketization of high-quality care.

On their websites, a handful of agencies use self-made quality seals or refer to certificates from marketing companies to distinguish themselves from their competitors by advertising high quality. In 2015, the three non-profit organizations Caritas, Hilfswerk, and Volkshilfe important players not only in the field of live-in care but in Austria's social service sector more generally - implemented their own exclusive quality seal labelled safe.competent.fair (sicher.kompetent.fair) ${ }^{17}$ and established standards they commit themselves to. This includes, among other things, transparent contracts, minimum qualification levels of brokered care workers, a standardized case management with regular quality controls, and native-speaking contacts for personal carers. Like the above-mentioned private agencies, the three non-profit organizations display their seal prominently in their (online) advertising. By referring to the agreed standards, they try to strengthen their image as high-quality providers as well as their prominent market position (Aulenbacher/Leiblfinger 2019).

Whereas the non-profit organizations' quality seal is not open for other agencies, since March 2019, agencies based in Austria can apply for the Austrian quality certificate for brokering agencies in 24h-care (ÖQZ-24, Österreichisches Qualitätszertifikat für

\footnotetext{
${ }^{17}$ https://www.pflegen.at/sicher-kompetent-fair
} 
Vermittlungsagenturen in der 24-Stunden-Betreuung $)^{18}$, a state-run quality seal developed by the Federal Ministry of Social Affairs. Its introduction had been demanded for years by many agencies and stakeholders „to establish a MINIMUM STANDARD OF QUALITY ${ }^{19}$ for all agencies, [...] from which also the CARERS benefit" (Interview 89: 423-428). It combines the dimensions of competition and protection: the quality seal is supposed to lead to fairer competition, based not only on prices but also on quality; households are to benefit from a better comparability of agencies and can rely on fixed matching and care standards. Stronger political regulations in this perspective can contribute to a positive impact of market mechanisms on care quality: "[W]e really believe that a bit of competition, well embedded, well organized and also with a socially tiered tariff [...] somewhat helps to consistently ensure customer orientation" (Interview 83: 1237-1241).

Which criterions the quality seal should be based on has been a matter of controversy, indicating the heterogeneity of actors as well as agencies' differing business concepts and interests. Suggestions ranged from certain qualifications of agency employees and care workers to limitations of agency fees or contractual penalties to the prohibition of the authorization to collect payments. The certificate that was eventually introduced mainly demands compliance with legal regulations for agencies; only the preparation of the needs assessment at the beginning of the care arrangement as well as regular, at least quarterly home visits by registered nurses go beyond the existing legal requirements. By the end of 2019, 16 agencies - among them most of those agencies acting as public stakeholders - successfully completed the voluntary certification process. ${ }^{20}$

While many interviewees see the quality seal, especially if linked to a higher public allowance, as a step towards higher quality in live-in care and additionally suggest a certification of carers, others underline that even if this could improve the quality of care, it is insufficient to substantially improve the working and living conditions of personal carers. They identify a number of problems, among them the disputes arising from the care workers entering established household and familial orders, jealousy, (sexual) harassment as well as excessive expectations of family members concerning times of availability and tasks of the carers (Aulenbacher/Leiblfinger 2019). As some households do not even meet minimal requirements for livein carers like sufficient board and a separate, lockable room, "neutral, preferably state-run, quality controls in households" (Interview 12: 584-585) would be necessary. From these perspectives, the state and politics are called on to improve the live-in care arrangement by controlling the actors in the field and combining public support and funding with conditions that may be better suited to guarantee both decent care and decent work.

\section{Conclusion}

In the Austrian case of live-in care, welfare and family conservatism and market-fundamentalism conflate into a legalized and therefore widely legitimized and accepted form of brokered

\footnotetext{
${ }^{18}$ https://oeqz.at/

${ }^{19}$ Intonations by our interview partners were transcribed in capitals.

${ }^{20} \mathrm{https}$ ://oeqz.at/zertifizierte-vermittlungsagenturen/
} 
self-employment. It nevertheless continues to be criticized and contested. From a Polanyian perspective, we have demonstrated that the mechanisms of supply and demand and "the signals of prices, costs and profits" (Deutschmann 2019: 22) regulate the brokering of live-in care in the (dis)embedded care market with the effect of producing a fundamental contradiction between decent care and decent work and jeopardizing the fictitious commodities labor and care. This contradiction, the threat to care and self-care and the accompanying disputes as a kind of everyday life experience of marketization has led different actors to discuss the established care arrangement in terms that indicate the need for a search for protection from market driven dynamics by organizing care workers' resistance and protest, establishing professional standards and addressing the state and politics. While agencies try to interfere with the markets to improve the rules of competition, the destructive commodification of labor and care seems to be a strong motivation for stakeholders as representatives of different parts of society or protagonists of a care workers' movement to demand changes in the rules of the care arrangement instead of allowing it to function in accordance with market mechanisms. Both - the attempts to mitigate market-driven dynamics as well as the search for alternative forms to organize livein care or for new forms of caring - are part of the contemporary double movement around live-in care in Austria. They can be understood as reactions to a legalized, formalized, and professionalized model of care provision that promises decent care for the elderly while simultaneously lacking the conditions for high-quality care and decent work as well as for the care givers' self-care.

\section{Acknowledgements}

We thank Simone Leiber and August Österle for their important comments on our Polanyian perspective and our analysis of live-in care, and Monica Budowski, Nina Jany, and Sebastian Schief for the inspiring discussion about decent work. Furthermore, we would like to express our gratitude to the two anonymous reviewers whose suggestions helped improve and clarify this manuscript and Jan-Peter Herrmann for his proofreading.

\section{Declaration of Conflicting Interests}

The authors declared no potential conflicts of interest with respect to the research, authorship, and/or publication of this article.

\section{Funding}

This work has been funded by the Austrian Science Fund FWF, project no. I 3145 G-29, Decent Care Work? Transnational Home Care Arrangements. 


\section{References}

Abraham, Margaret and Brigitte Aulenbacher (2019). Contested capitalism: some reflections on countermovements, social justice and the task for sociology. In: Dörre, Klaus, Hartmut Rosa, Karina Becker, Sophie Bose, and Benjamin Seyd (eds.). Große Transformation? Zur Zukunft moderner Gesellschaften (Sonderband des Berliner Journals für Soziologie). Wiesbaden: Springer VS, 527-547.

Anderson, Bridget and Isabel Shutes (eds.) (2014). Migration and Care Labour. Theory, Policy and Politics. Basingstoke: Palgrave Macmillan.

Appelt, Erna and Eva Fleischer (2014). Familiale Sorgearbeit in Österreich: Modernisierung eines konservativen Care-Regimes? Soziale Welt, Sonderband 20, 401-422.

Artus, Ingrid, Peter Birke, Stefan Kerber-Clasen, and Wolfgang Menz (eds.) (2017). Sorge-Kämpfe: Auseinandersetzungen um Arbeit in sozialen Dienstleistungen. Hamburg: VSA.

Aulenbacher, Brigitte (2020). Auf neuer Stufe vergesellschaftet: Care und soziale Reproduktion im Gegenwartskapitalismus. In: Becker, Karina, Kristina Binner, and Fabienne Décieux (eds.). Gespannte Arbeits- und Geschlechterverhältnisse im Marktkapitalismus: Zwischen Emanzipation und Ausbeutung. Wiesbaden: Springer VS, 125-147.

Aulenbacher, Brigitte and Maria Dammayr (2014). Zwischen Anspruch und Wirklichkeit: Zur Ganzheitlichkeit und Rationalisierung des Sorgens und der Sorgearbeit. Soziale Welt, Sonderband 20, 125-140.

Aulenbacher, Brigitte, Fabienne Décieux, and Birgit Riegraf (2018a). The Economic Shift and Beyond: Care as a Contested Terrain in Contemporary Capitalism. Current Sociology Monograph 66(4), 517 530 .

Aulenbacher, Brigitte, Fabienne Décieux, and Birgit Riegraf (2018b). Capitalism goes care: Elder and child care between market, state, profession, and family and questions of justice and inequality. Equality, Diversity and Inclusion 37(4), 347-360.

Aulenbacher, Brigitte and Michael Leiblfinger (2019). The "fictitious commodity" care and the reciprocity of caring: A Polanyian and neo-institutionalist perspective on the brokering of 24-hour care. In: Atzmüller, Roland, Brigitte Aulenbacher, Ulrich Brand, Fabienne Décieux, Karin Fischer, and Birgit Sauer (eds.). Capitalism in Transformation: Movements and Countermovements in the $21^{\text {st }}$ Century. Cheltenham and Northampton: Edward Elgar, 245-260.

Aulenbacher, Brigitte, Michael Leiblfinger, and Veronika Prieler (2020). „Jetzt kümmern sich zwei slowakische Frauen abwechselnd um meinen Vater ...“": Institutionelle Logiken und soziale Ungleichheiten in der agenturvermittelten 24h-Betreuung. In: Seeliger, Martin and Julia Gruhlich (eds). Intersektionalität, Arbeit und Organisation. Weinheim and Basel: Beltz Juventa, 127-141.

Bachinger, Almut (2009). Der irreguläre Pflegearbeitsmarkt: Zum Transformationsprozess von unbezahlter in bezahlte Arbeit durch die 24-Stunden-Pflege. Dissertation. Universität Wien, Wien.

Bachinger, Almut (2010). 24-Stunden-Betreuung - Gelungenes Legalisierungsprojekt oder prekäre Arbeitsmarktintegration? SWS-Rundschau 50(4), 399-412.

Bachinger, Almut (2014). 24-Stunden-Betreuung - ganz legal? Intersektionale Regime und die Nutzung migrantischer Arbeit. In: Aulenbacher, Brigitte and Maria Dammayr (eds.). Für sich und andere sorgen. Krise und Zukunft von Care in der modernen Gesellschaft. Weinheim und Basel: Beltz Juventa, 127-137. 
Block, Fred and Margaret R. Somers (2014). The Power of Market Fundamentalism: Karl Polanyi's Critique. Cambridge: Harvard University Press.

Bahna, Miloslav and Martina Sekulová (2019). Crossborder Care. Lessons from Central Europe. Cham: Palgrave.

Blofield, Merike and Merita Jokela (2018). Paid domestic work and the struggles of care workers in Latin America. Current Sociology 66(4), 531-546.

Buğra, Ayşe and Kaan Ağartan (eds.) (2007). Reading Karl Polanyi for the Twenty-First Century: Market Economy as a Political Project. New York: Palgrave Macmillan.

Burawoy, Michael (2015). Facing an unequal world. Current Sociology 63(1), 5-34.

Chau, Huey Shy, Katharina Pelzelmayer, and Karin Schwiter (2018). Short-term Circular Migration and Gendered Negotiation of the Right to the City: The Case of Migrant Live-in Care Workers in Basel, Switzerland. Cities 76, 4-11.

Chorus, Silke (2013). Care-Ökonomie im Postfordismus. Perspektiven einer integralen Ökonomie-Theorie. Münster: Westfälisches Dampfboot.

Dammayr, Maria (2019). Legitime Leistungspolitiken? Leistung, Gerechtigkeit und Kritik in der Altenpflege. Weinheim und Basel: Beltz Juventa.

Décieux, Fabienne, Karina Becker, and Yalcin Kutlu (2020). Permanenter Notstand und der Kampf um gute Sorge(arbeit) - Polanyi'sche Doppelbewegungen in der Marktgesellschaft. Industrielle Beziehungen 4/2019, 386-406.

Der Standard (2018). Wie abhängig 24-Stunden-Betreuerinnen von ihren Agenturen sind. Last accessed 31.05.2019 on https://derstandard.at/2000084041380.

Der Standard (2019). Als man Elena die Stimme nahm. Last accessed 31.05.2019 on https://derstandard.at/2000096455290.

Der Standard (2020). 24-Stunden-Pflegerin wird von Mitarbeiterin der eigenen Gewerkschaft geklagt. Last accessed 05.03.2020 on https://www.derstandard.at/2000114127245.

Deutschmann, Christoph (2019). Disembedded Markets: Economic Theology and Global Capitalism. Milton Park: Routledge.

Die Presse (2018). Eine Gewerkschaft für die Ich-AGs. Last accessed 31.05 .2019 on https://diepresse.com/home/meinung/gastkommentar/5462112.

Dörre, Klaus, Martin Ehrlich, and Tine Haubner (2014). Landnahmen im Feld der Sorgearbeit. In: Aulenbacher, Brigitte, Birgit Riegraf, and Hildegard Theobald (eds.). Sorge: Arbeit, Verhältnisse, Regime. Baden-Baden: Nomos, 111-128.

Falter (2017). Harte Bandagen: Die 24-Stunden-Betreuung ist für viele alte Menschen ein Segen. Für viele Vermittlungsagenturen ist es ein lukratives Geschäft. Die Betreuerinnen zahlen häufig drauf. Falter 48/2017, 18-21.

Falter (2018). Frau Popa will reden. Die Betreuerinnen zahlen häufig drauf. Falter 4/2018, 18-20.

Fraser, Nancy (2012). Can society be commodities all the way down? Polanyian reflections on capitalist crisis. halshs-00725060. 
Haidinger, Bettina (2016). Flexibilität, Absicherung und Interessenvertretung in der 24-Stunden-Betreuung ... grenzenlos? In: Weicht, Bernhard, and August Österle (eds.). Im Ausland zu Hause pflegen. Die Beschäftigung von MigrantInnen in der 24-Stunden-Betreuung. Wien: LIT, 87-114.

Haubner, Tine (2017). Die Ausbeutung der sorgenden Gemeinschaft. Laienpflege in Deutschland. Frankfurt/New York: Campus Verlag.

Karner, Christian and Weicht, Bernhard (eds.) (2016). The Commonalities of Global Crises: Markets, Communities and Nostalgia. Palgrave Macmillan.

Klinger, Cornelia (2013). Krise war immer ... Lebenssorge und geschlechtliche Arbeitsteilung in sozialphilosophischer und kapitalismuskritischer Perspektive. In: Appelt, Erna, Brigitte Aulenbacher, and Angelika Wetterer (eds.). Gesellschaft: Feministische Krisendiagnosen. Münster: Westfälisches Dampfboot, 82-104.

Klinger, Cornelia (2014). Selbst- und Lebenssorge als Gegenstand sozialphilosophischer Reflexionen auf die Moderne. Soziale Welt, Sonderband 20, 21-39.

Konsument (2018). 24-Stunden-Betreuung. Handlungsbedarf. Konsument 6/2018, 40-41.

Kretschmann, Andrea (2010). Mit Recht regieren? Zur Verrechtlichung transmigrantischer 24-Stunden-Carearbeit in österreichischen Privathaushalten. In: Scheiwe, Kirsten and Johanna Krawietz (eds.). Transnationale Sorgearbeit. Rechtliche Rahmenbedingungen und gesellschaftliche Praxis. Wiesbaden: VS Verlag für Sozialwissenschaften, 199-226.

Kurier (2017a). Analyse: Woran die 24-Stunden-Pflege krankt. Last accessed 31.05.2019 on https://kurier.at/wirtschaft/analyse-woran-die-24-stunden-pflege-krankt/294.274.341.

Kurier (2017b). Riesiger Schwarzmarkt mit gefälschten Pflegezertifikaten. Last accessed 31.05 .2019 on https://kurier.at/wirtschaft/riesiger-schwarzmarkt-mit-gefaelschten-pflegezertifikaten/287.559.239.

Kurier (2018). Das schmutzige Geschäft mit der 24-Stunden-Betreuung. Last accessed 31.05.2019 on https://kurier.at/leben/das-schmutzige-geschaeft-mit-der-24-stunden-betreuung/400302084.

Leiblfinger, Michael (2020). „Wie liebevoll kümmernde Angehörige“: Die Vergeschlechtlichung von Care und deren Entnennung als Arbeit am Beispiel der 24-Stunden-Betreuung. In: Pfeil, Walter J., Astrid Reichel, and Sabine Urnik (eds.). Pflege und Betreuung - Who cares? Wien: Manz, 1-13.

Leiblfinger, Michael and Veronika Prieler (2018). Elf Jahre 24-Stunden-Betreuung in Österreich: Eine Policy- und Regime-Analyse. Linzer Beiträge zu Wirtschaft - Ethik - Gesellschaft 9. Katholische Privat-Universität Linz.

Lutz, Helma (2017). Care as a fictitious commodity: Reflections on the intersections of migration, gender and care regimes. Migration Studies 5(3), 356-368.

Österle, August (2016). 24-Stunden-Betreuung und die Transnationalisierung von Pflege und Betreuung: Aktuelle Dimensionen und wohlfahrtsstaatliche Implikationen. In: Weicht, Bernhard and August Österle (eds.). Im Ausland zu Hause pflegen: Die Beschäftigung von MigrantInnen in der 24Stunden-Betreuung. Wien: LIT, 247-269.

Österle, August and Gudrun Bauer (2012). Home care in Austria: the interplay of family orientation, cash-for-care and migrant care. Health and Social Care in the Community 20(3), 265-273.

Österle, August and Gudrun Bauer (2016). The Legalization of Rotational 24-hour Care Work in Austria: Implications for Migrant Care Workers. Social Politics 23(2), 192-213. 
Österle, August, Andrea Hasl, and Gudrun Bauer (2013). Vermittlungsagenturen in der 24-h-Betreuung. WISO - Wirtschafts- und sozialpolitische Zeitschrift 36(1), 159-172.

Polanyi, Karl (2001). The Great Transformation: The Political and Economic Origins of Our Time. Boston: Beacon Press.

Prieler, Veronika (2020). Autonome Ältere, Pflegefälle und kontrollbedürftige Selbstständige: Subjektkonstruktionen in der 24-Stunden-Betreuung in Österreich. Schweizerische Zeitschrift für Soziologie 46(2), 259-280.

Rossow, Verena and Simone Leiber (2017). Zwischen Vermarktlichung und Europäisierung: Die wachsende Bedeutung transnational agierender Vermittlungsagenturen in der häuslichen Pflege in Deutschland. Sozialer Fortschritt 66(3-4), 285-302.

Rudolph, Clarissa and Katja Schmidt (eds.) (2019). Interessenvertretung und Care: Voraussetzungen, Akteure und Handlungsebenen. Münster: Verlag Westfälisches Dampfboot.

Schaup, Fabian S. A. (2020). Rechtsfragen der 24-Stunden-Betreuung. In: Pfeil, Walter J., Astrid Reichel, and Sabine Urnik (eds.). Pflege und Betreuung - Who cares? Wien: Manz, 61-81.

Schilliger, Sarah (2014). Pflegen ohne Grenzen? Polnische Pendelmigrantinnen in der 24h-Betreuung: Eine Ethnographie des Privathaushalts als globalisiertem Arbeitsplatz. Dissertation, Universität Basel.

Schilliger, Sarah and Katharina Schilling (2017). Care-Arbeit politisieren: Herausforderungen der (Selbst-)Organisierung von migrantischen 24h-Betreuerinnen. Femina Politica - Zeitschrift für Feministische Politik 26, 101-116.

Schwenken, Helen (2006). Rechtlos, aber nicht ohne Stimme: Politische Mobilisierungen um irreguläre Migration in die Europäische Union. Bielefeld: transcript Verlag.

Shire, Karen (2015). Family supports and insecure work: The politics of household service employment in Conservative Welfare Regimes. Social Politics 22(2), 193-219.

Somers, Margaret R. (2018). Utopianism and the reality of society: Decoding Polanyi's socialism, freedom and the alchemy of misrecognition. In: Brie, Michael and Claus Thomasberger (eds.). Karl Polanyi's vision of a socialist transformation. Montréal: Black Rose Books, 91-109.

Steiner, Jennifer (2020). „Guter Lohn für gute Arbeit“? Legitimation und Kritik im Regulierungsprozess der Rund-um-die-Uhr-Betreuung betagter Menschen in Schweizer Privathaushalten. Schweizerische Zeitschrift für Soziologie 46(2), 281-303.

Steiner, Jennifer, Veronika Prieler, Michael Leiblfinger, and Aranka Benazha (2019). Völlig legal!? Rechtliche Rahmung und Legalitätsnarrative in der 24h-Betreuung in Deutschland, Österreich und der Schweiz. Österreichische Zeitschrift für Soziologie 44(1), 1-19.

Tronto, Joan C. (2017). There is an alternative: homines curans and the limits of neoliberalism. International Journal of Care and Caring 1(1), 27-43.

Völker, Susanne and Michèle Amacker (eds.) (2015). Prekarisierungen: Arbeit, Sorge und Politik. Weinheim und Basel: Beltz Juventa.

Winker, Gabriele (2015). Care Revolution: Schritte in eine solidarische Gesellschaft. Bielefeld: transcript Verlag.

WKO - Stabsabteilung Statistik (2020). Personenberatung und Personenbetreuung: Branchendaten. Wien. Last accessed 25.02.2020 on http://wko.at/statistik/BranchenFV/B 127.pdf. 